\title{
Vijf opties voor milieuverslaggeving door ondernemingen
}

\section{Drs. A. Huizing}

\section{Inleiding}

Wordt een jaarlijks te publiceren milieuverslag een nieuwe loot aan de stam van periodieke ondernemingsverslagen? En zo ja, in welke vorm, met welke inhoud, en door wie wordt het gecontroleerd? Dit zijn klemmende vragen die met het debat over bedrijfsinterne milieuzorgsystemen ${ }^{1}$ (hierna BIM's) zijn opgekomen.

In dit artikel worden in verkennende zin vijf opties voor milieuverslaggeving besproken. Vertrekpunten daarbij zijn de meningen van de overheid, accountants, werkgevers-, milieu- en werknemersorganisaties over milieuverslaggeving, en de bestaande wettelijke regelingen omtrent en ervaringen met andere vormen van jaarverslaggeving (Titel 9 BW 2 en de Arbeidsomstandighedenwet respectievelijk sociale en maatschappelijke verslaggeving).

De vijf opties voor milieuverslaggeving zijn:

- een maatschappelijk jaarverslag met daarin milieu-informatie;

- een milieuverslag a la het financiële jaarverslag;

- een milieuverslag a la het arbeidsomstandighedenverslag;

- een milieuverslag a la het sociale jaarverslag;

- een milieuparagraaf in het bestuurs-, arbeidsomstandigheden- of sociale verslag.

In paragraaf 2 wordt kort ingegaan op de verschillende standpunten van de genoemde groeperingen. In de vijf paragrafen daarna worden achtereenvolgens de vijf opties voor milieuverslagge- ving behandeld. Tot slot volgen in paragraaf 8 enkele afsluitende opmerkingen.

\section{Verschillende standpunten rond milieuverslaggeving}

De standpunten van de overheid, accountants, werkgevers-, milieu- en werknemersorganisaties over onder meer vorm, inhoud en controle van milieuverslaggeving lopen scherp uiteen.

De overheid voert een steeds krachtiger milieubeleid (inzake emissiebeperking, bodemsanering, aansprakelijkheid, en dergelijke). Onderdeel daarvan is de notitie Bedrijfsinterne milieuzorg (VROM, 1989). Uit deze notitie blijkt dat alle 10.000 tot 12.000 grotere bedrijven met bijzondere milieurisico's in 1995 moeten beschikken over een integraal BIM. ${ }^{2}$ Kleinere, hinderwetplichtige bedrijven moeten rond die datum duidelijke stappen hebben ondernomen tot een partieel $\mathrm{BIM}$. Van een wettelijke regeling is voorlopig afgezien, maar de overheid houdt wel een stok achter de deur. Als bij het opmaken van een tussenbalans in 1992 blijkt dat er weinig vordering is gemaakt met het invoeren van BIM's, dan zal daaromtrent alsnog wetgeving volgen. In de tussentijd tracht de overheid via proefprojecten, voorlichting, convenanten, subsidies, enzovoort, te bevorderen dat het milieubelang wordt opgenomen als een integraal onderdeel in de doelstellingen en activiteiten van maatschappelijke groe-

Drs. A. Huizing studeerde Economie aan de Universiteit van Amsterdam en is werkzaam als universitair docent aan die zelfde universiteit, Faculteit der Economische Wetenschappen en Econometrie, vakgroep Bestuurlijke informatiekunde. 


\section{MAB}

pen. Dit wordt de verinnerlijking van het milieubeleid genoemd (VROM, 1989: 9). Daarmee wordt expliciet tot uitdrukking gebracht dat het maatschappelijk middenveld (het bedrijfsleven, de milieuorganisaties, enzovoort) een eigen verantwoordelijkheid voor het milieu heeft.

Milieurapportage ${ }^{3}$ is volgens de overheid (VROM, 1989: 25) een onmisbaar element van het BIM. Overheidsinstanties, maar idealiter ook derden, dienen te worden bericht over de werking en de resultaten van het BIM. Daarnaast zou de milieurapportage tegemoet moeten komen aan de reeds bestaande rapportageverplichting van meetgegevens, afgiften, en dergelijke, vastgelegd in vergunningvoorschriften of wettelijke bepalingen. Doordat op dergelijke rapportages de Wet Openbaarheid van Bestuur van toepassing is, is de aan de overheid verstrekte informatie in beginsel voor iedereen beschikbaar (met uitzondering van bedrijfsvertrouwelijke gegevens die hiervan kunnen worden uitgesloten).

Binnen het accountantsberoep is nog geen eensluidend standpunt geformuleerd over BIM's en de betrokkenheid van de accountant daarbij. Inzake milieuverslaggeving variëren de pleidooien van 'thans nog niet aan de orde' (Piet, 1990: 252) tot en met een hernieuwde belangstelling voor de maatschappelijke berichtgevingstheorie (Bindenga, 1989; Derwent, 1989).

De accountants worstelen vooralsnog onder meer met vragen over de stoffenregistratie, die een kernonderdeel van het milieuverslag zou kunnen worden. Stoffenregistratie is een overkoepelend begrip voor het opstellen van een stoffenbalans, het opzetten van een stoffenboekhouding en het registreren van bepaalde stoffen of stoffenstromen. Enkele vragen die ermee worden opgeroepen, zijn: biedt de interne controle in het BIM voldoende steun bij de accountantscontrole, kunnen nieuwe geschikte controletechnieken worden ontwikkeld, en is de accountant wel voldoende deskundig om omzettingsprocessen te beoordelen? Zonder deze problemen te ontkennen, vinden sommige accountants dat stoffenregistraties in principe controleerbaar zijn en dus ook van een accountantsverklaring kunnen worden voorzien (Blokdijk, 1989: 87). Anderen daar- entegen achten de accountant daartoe hoe dan ook niet in staat (Wilschut, 1990: 17).

De werkgeversorganisaties VNO en NCW (1985: 6) stellen dat het opstellen van betrouwbare en sluitende stoffenregistraties onmogelijk en overbodig is. Mede hierom keren zij zich ook tegen de idee van de milieu-accountant. Meer in zijn algemeenheid vindt het georganiseerde bedrijfsleven (VNO/NCW, 1986: 9) dat het BIM geen nieuwe regelgeving moet oproepen, en dat de overheidscontrole zou kunnen worden beperkt tot de opzet en werking van het BIM. Een wettelijk verplicht milieuverslag wordt derhalve ook afgewezen. Als alternatief daarvoor noemen VNO en NCW (1988: 22) het (vrijwillig) opnemen van een milieuparagraaf in het bestuurs- of in het sociale verslag. Bedrijven met een relatief grote milieubelasting zouden, eveneens vrijwillig, een apart milieuverslag kunnen uitbrengen (VNO/NCW, 1990: 24). Daarnaast kan de buitenwereld worden voorgelicht via persconferenties, open dagen, excursies, enzovoort.

De milieu- en werknemersorganisaties (LMO, 1989: 10; FNV, 1990: 3) bepleiten daarentegen wel een wettelijk verplicht milieuverslag (inclusief stoffenregistraties), dat door een externe milieuaccountant zou moeten worden gewaarmerkt. Een dergelijke verplichting is in hun ogen een onmisbare voorwaarde voor een effectieve milieuzorg in bedrijven. Voorts waarschuwen vooral de milieu-organisaties tegen het verminderen van het overheidstoezicht, dat volgens hen dreigt te worden afgeruild tegen het vrijwillig invoeren van BIM's door het bedrijfsleven (LMO, 1989: 7).

Ten aanzien van het controlevraagstuk merkt de overheid op dat het beoordelen van BIM's en milieurapportages primair een taak is van het vergunningverlenende gezag ${ }^{4}$ (VROM, 1989: 35). Zij is niet overtuigd van de voordelen van verificatie van de gehele milieurapportage door een externe deskundige. Wel zouden bepaalde onderdelen daarvan vergezeld kunnen gaan van een deskundigenverklaring (bijvoorbeeld bij emissie- en afvalstoffengegevens).

Samenvattend kan worden gesteld dat er een sterke maatschappelijke druk tot milieuverslaggeving bestaat. Ook de werkgeversorganisaties 


\section{MAB}

zien het nut van het verstrekken van milieu-informatie in. Zij wijzen echter een wettelijk verplicht milieuverslag af, in tegenstelling tot de milieu- en werknemersorganisaties. De overheid neemt een tussenpositie in. Zij raadt het bedrijfsleven aan de komende jaren ervaring op te doen met milieuverslaggeving (VROM, 1989: 34). Mocht deze raad onvoldoende weerklank vinden, dan kan alsnog wetgeving volgen. Overigens, rond milieuverslaggeving bestaan reeds wetgevingen (milieu-effectrapportage, post-Seveso richtlijn, enzovoort). Bepaalde onderdelen die in een verplicht milieuverslag aan de orde zouden kunnen komen, kunnen al worden voorgeschreven (onder meer periodieke rapportages over emissiegegevens en afvalstromen). De regering heeft dan ook aangekondigd bij de evaluatie van de invoering van BIM's in het bijzonder na te gaan of de bestaande wettelijke mogelijkheden voldoende zijn (VROM, 1989: 35). Op deze wijze versterkt zij haar beroep op het maatschappelijk middenveld om te gaan experimenteren met milieuverslaggeving.

\section{Milieu-informatie in een maatschappelijk verslag}

De maatschappelijke berichtgevingstheorie kent vele varianten, die in vele landen zijn ontwikkeld (zie Dekker, 1989). In Nederland is deze theorie uitgemond in de zogenaamde indicatorenbenadering (Bindenga, 1981; Schreuder, 1981). De onderneming dient volgens deze benadering te berichten aan een breed gedefinieerde kring van belanghebbenden over de door deze belanghebbenden relevant geachte effecten van de ondernemingsactiviteiten, liefst in één geïntegreerd verslag. Vele positieve en negatieve, financiële en niet-financiële ondernemingseffecten worden door de groepen belanghebbenden (vermogensverschaffers, financiële analisten, werknemers, en dergelijke) als relevant beschouwd, zoals uit de verrichte onderzoeken onder gebruikers van jaarverslagen is gebleken (onder meer Limperg Instituut, 1984). Milieu-effecten zijn hiervan slechts een onderdeel. Een maatschappelijk verslag bevat idealiter dan ook niet alleen milieuinformatie, maar bijvoorbeeld ook sociale en con- sumenteninformatie naast de meer gebruikelijke financiële en commerciële informatie. Een dergelijk geïntegreerd verslag biedt dus voor elk wat wils.

De maatschappelijke berichtgevingstheorie kende rond 1980 veel aanhangers in binnen- en buitenland, maar is sindsdien op de achtergrond geraakt. De huidige aandacht voor het milieu zou echter kunnen leiden tot een hernieuwde belangstelling voor deze theorie (Bindenga, 1989; Derwent, 1989).

Verdient de 'traditionele' maatschappelijke berichtgevingstheorie opnieuw onze aandacht nu de belangstelling voor het milieu en de berichtgeving daaromtrent toeneemt? Mijns inziens niet, omdat:

- de informatieverschaffers de maatschappelijke berichtgevingstheorie altijd links hebben laten liggen. De praktijk vertoont een voorkeur voor een gedifferentieerde berichtgeving per doelgroep of thema, daartoe al dan niet aangezet door de bestaande wet- en regelgeving (financiële, sociale en arbeidsomstandigheden-verslaggeving, enzovoort);

- een gedifferentieerde berichtgeving betere mogelijkheden biedt om de te verstrekken informatie qua vorm, inhoud en timing aan te passen aan doelgroepen of thema's. Een dergelijke berichtgeving verdient de voorkeur in onze pluriforme samenleving, waarin vele belangengroeperingen met uiteenlopende informatiebehoeften voorkomen (Huizing, 1987);

- het onduidelijk is tot welke belanghebbenden de onderneming zich moet wenden voor haar milieu-berichtgeving (de omwonenden?, de overheid?, de milieu-organisaties?). Het opstellen van zogenaamde belevingsindicatoren is in dit concrete geval uiterst moeilijk zo niet onmogelijk (Dekker, 1989: 148);

- (meer in het algemeen) de belanghebbenden of informatiegebruikers nauwelijks in staat zijn gebleken hun informatiebehoeften te definiëren. Brink (1989: 7) meent dan ook dat wij '...de gebruikers een poosje met rust moeten laten en ons moeten richten op de andere partij bij de verslaggeving, de ondernemingen dus'.

Een apart milieuverslag ligt om deze redenen 
meer in de lijn der verwachtingen. In de volgende drie paragrafen worden voor een dergelijke verslaggevingswijze drie opties uitgewerkt.

\section{Een milieuverslag à la het financieel jaarverslag}

Het is mogelijk dat gedetailleerde voorschriften ten aanzien van de vorm, inhoud, frequentie, enzovoort, van milieuverslaggeving zullen worden vastgelegd in een Wet op het Milieuverslag van Ondernemingen, conform Titel 9 BW 2 bij financiële verslaggeving. Het trekken van een parallel met Titel $9 \mathrm{BW} 2$ houdt tevens in dat het milieuverslag zou moeten worden gecontroleerd en gewaarmerkt door een externe deskundige (de milieu-accountant?). Een dergelijke wettelijke verankering van het milieuverslag wordt door de milieu- en werknemersorganisaties bepleit (LMO, 1989: 10; FNV, 1990: 3).

Deze optie heeft onder meer de volgende voordelen:

- een wettelijke verplichting tot milieuverslaggeving stimuleert bedrijven een goed functionerend BIM op te zetten (LMO, 1989: 10; FNV, 1990: 3);

- alle daartoe verplichte bedrijven worden ertoe aangezet zich te verantwoorden over hun milieubeleid in een apart milieuverslag dat toegankelijk is voor iedere geïnteresseerde. Zonder wettelijke dwang en daarbij behorende sanctiemiddelen zullen nooit alle bedrijven over de streep worden getrokken;

- door wettelijke normen en regels te stellen wordt de vergelijkbaarheid van milieuverslagen met die van andere bedrijven of jaren bevorderd;

- voor de overheid kan jaarlijkse milieurapportage dienen als uitgangspunt voor vruchtbaar periodiek overleg met het bedrijf, als hulpmiddel bij het stellen van prioriteiten met betrekking tot overheidstoezicht, en als instrument ten dienste van de controle op de naleving van milieuregels (VROM, 1989: 26);

- door aan het milieuverslag wettelijke eisen te stellen en door de verplichting tot onafhankelijke externe controle kan beter worden voorkomen dat milieuverslaggeving blijft steken in public relations, waarbij de goede punten worden geaccentueerd en de slechte verhuld of verzwegen.

Tegen wetgeving kunnen de volgende argumenten worden aangevoerd:

- voor een Wet op het Milieuverslag van Ondernemingen zullen onder meer (gedetailleerde) inhouds- en vormgevingscriteria moeten worden geformuleerd, waardoor moeilijk recht kan worden gedaan aan verschillen tussen bedrijven in milieurisico's, bedrijfsomvang, de aard van de activiteiten, produkt- en proceskenmerken en dergelijke;

- wetgeving kan een bevriezend effect hebben op de berichtgevingspraktijk. Ervaringen in Frankrijk met wetgeving rond sociale verslaggeving (Bilan Social) hebben aangetoond dat sociale verslagen in de experimenteerfase dikwijls veelbelovender en informatiever waren dan de verslagen die na het van kracht worden van de wet verschenen (Van Hoorn, 1981: 109). In dit kader past ook de opmerking van Van de Poel (1988: 20) dat er bitter weinig onderzoek is verricht naar het nut van regelgeving;

- regelgeving brengt kosten met zich mee, zowel voor de overheid (controle, rechtspraak, enzovoort) als voor het bedrijfsleven (publiceren van het milieuverslag, controle door externe deskundige, concurrentienadeel, enzovoort).

Daarnaast pleiten tegen wetgeving argumenten van een meer tijdelijke aard. De gewenste vorm en inhoud van milieuverslaggeving is nog betrekkelijk weinig onderzocht (onder andere wel in VROM, 1989: 34; LMO, 1989: 11). Bovendien staat voorlopig nog niet vast of overheidscontrole dan wel een geprivatiseerde vorm van controle de voorkeur verdient, terwijl het bij dit laatste nog maar de vraag is of waarmerking van het milieuverslag door een externe deskundige, al dan niet aan de hand van stoffenregistraties, wel mogelijk is. Deze en andere problemen zullen de komende jaren moeten worden opgelost. Tot die tijd is wetgeving prematuur.

Een wet op het Milieuverslag van Ondernemingen is derhalve stellig een optie, maar wel één die pas in de toekomst een rol kan gaan spelen. Eerst moeten de praktische en juridische haalbaarheid ervan verder in kaart worden gebracht, moet het 


\section{MAB}

bedrijfsleven in de gelegenheid worden gesteld te experimenteren met milieuverslagen, en moeten de genoemde voor- en nadelen van wetgeving tegen elkaar worden afgewogen.

\section{Een milieuverslag à la het arbeidsomstandighedenjaarverslag (arboverslag)}

De verplichting tot het uitbrengen van een arboverslag geldt voor bedrijven die ook een jaarplan ${ }^{5}$ moeten hebben. Publikatieplichtig zijn tevens de categorieën bedrijven die daartoe via een Algemene Maatregel van Bestuur (AMvB) worden aangewezen. Indien een sociaal jaarverslag wordt uitgebracht (ingevolge artikel 31b, lid 1 van de Wet op de Ondernemingsraden), mag het arboverslag daarin worden opgenomen. Deze regelingen staan vermeld in artikel 10 van de Arbowet (1980), die gefaseerd is ingevoerd. Het eerste verplichte verslagjaar, voor ondernemingen met meer dan 100 werknemers, was 1986.

Er zijn ten minste twee essentiële verschillen tussen Titel 9 BW 2 en de Arbowet, die leiden tot een aparte optie voor milieuverslaggeving. Het eerste verschil betreft de wijze waarop de externe controle op de jaarverslaggeving is geregeld; het tweede de mate van detaillering van de voorschriften.

In Titel 9 BW 2 is de externe controle geprivatiseerd (accountantscontrole), terwijl de controle in de Arbowet bij de overheid (Arbeidsinspectie) ligt. Dit principiële onderscheid speelt ook bij milieuverslaggeving: wie wordt belast met de externe controle op het milieuverslag? Zoals reeds in paragraaf 2 is vermeld, legt de overheid deze taak primair bij de vergunningverlenende gezagen. Een regeling als in Titel $9 \mathrm{BW} 2$ wordt derhalve door haar afgewezen.

Het overlaten van de controle op de milieurapportage aan de vergunningverlenende gezagen, al dan niet in combinatie met de Inspectie Milieuhygiëne, zou voor het bedrijfsleven een aanzienlijk voordeel opleveren. De controlekosten komen dan namelijk niet voor rekening van het bedrijfsleven, zoals bij de accountantskosten in Titel $9 \mathrm{BW}$ 2, maar ten laste van de overheid c.q. samenleving. Het principe 'de vervuiler betaalt', waarvan de overheid zegt uit te gaan in haar milieubeleid (NMP, 1989: 12), wordt in dit geval dus niet strikt toegepast.

Het tweede verschil tussen Titel 9 BW 2 en de Arbowet betreft de mate van detaillering van de regelgeving. In tegenstelling tot Titel $9 \mathrm{BW} 2$ is de Arbowet een raamwet. Dit houdt in dat het maatschappelijk middenveld (i.c. het bedrijfsleven, ondernemingsraden en andere betrokkenen) primair zelf verantwoordelijk is voor het realiseren van de doelstelling(en) en dat de wetgever zich beperkt tot het aangeven van die doelstelling(en), de uitgangspunten, enzovoort. In een raamwet wordt een bepaald minimum geregeld (bijvoorbeeld ten aanzien van de verslagplicht, werkingssfeer, sanctie- en beroepsmogelijkheden), terwijl de nadere invulling ervan met advies van de sociale partners kan plaatsvinden via de AMvB.

Een milieuverslag a la het arboverslag is mijns inziens een serieuzere optie dan een Wet op het Milieuverslag van Ondernemingen. De overheid stelt met haar verinnerlijkingsbeleid nadrukkelijk dat alle maatschappelijke groepen een eigen verantwoordelijkheid hebben inzake het milieu (VROM, 1989: 9). Een raamwet met invulling daarvan via de $A M v B$, waarvoor de participatie van de betrokkenen wordt verlangd, sluit hierbij goed aan. Een dergelijke wet kan wellicht opgaan in de Wet algemene bepalingen Milieuhygiëne. Verdere voordelen van een raamwet ten opzichte van een Wet op het Milieuverslag van Ondernemingen liggen in de meer flexibele sturingsmogelijkheden via de AMvB. Regelingen kunnen van toepassing worden verklaard voor bepaalde categorieën bedrijven, verplicht te behandelen thema's in het jaarverslag kunnen beter worden afgestemd op branche-specifieke milieuproblemen, deze thema's kunnen sneller wisselen als de actualiteit daarom vraagt, enzovoort. Echter, de in de vorige paragraaf genoemde argumenten pro en contra wetgeving gelden mutatis mutandis ook hier. De vele nog bestaande onduidelijkheden over milieuverslaggeving staan het reeds nu voorbereiden van een raamwet a la de arbowet in de weg. Het afzien van deze vorm van regelgeving, althans voorlopig nog, verdient dan ook aanbeveling. 


\section{MAB}

\section{Een milieuverslag à la het sociale jaarverslag}

Naast de in de vorige twee paragrafen behandelde publiekrechtelijke vormen van regelgeving kan worden gedacht aan privaatrechtelijke initiatieven van het bedrijfsleven of andere maatschappelijke groepen. Zo is het sociale jaarverslag in ons land ingeburgerd geraakt zonder een wettelijke regeling. Daaraan zijn echter wel andere vormen van regelgeving te pas gekomen, met name de collectieve arbeidsovereenkomst (CAO). Naast de CAO somt Van Hoorn (1981: 99) een aantal andere alternatieven voor wetgeving op: de code, het sociaal statuut, de opdracht tot regelgeving en regelgeving voortvloeiend uit het centrale overleg tussen de sociale partners. ${ }^{6}$

Bij het vertalen van deze alternatieven naar milieuverslaggeving ontstaat echter onmiddellijk een probleem. De positie die de werknemersvertegenwoordigers in Nederland innemen is bij lange na niet te vergelijken met die van de milieuorganisaties. $\mathrm{Er}$ is in deze zin geen 'vakbeweging voor het milieu' en geen instituut vergelijkbaar met de ondernemingsraad. Het maatschappelijk middenveld op milieugebied lijkt derhalve vooralsnog onvoldoende geïnstitutionaliseerd en geprofessionaliseerd om de genoemde alternatieven te vertalen naar milieuverslaggeving.

Het in januari 1989 afgesloten milieuconvenant tussen VNO en FNV was mede daarom zo verrassend. ${ }^{7}$ Zouden de werknemersorganisaties - in nauwe samenwerking met de milieubeweging kunnen optreden als hoeders van het milieubelang? Dit moet bepaald niet worden uitgesloten. De werkgevers en werknemers gaan in gezamenlijk overleg het NMP verder uitwerken (invoering BIM, werknemersrechten op milieugebied en dergelijke). Dit zou kunnen leiden tot het opnemen van concrete bepalingen over milieuverslaggeving in bedrijfstak- en ondernemings-CAO's. Zoals gezegd is op deze wijze ook de ontwikkeling van sociale verslaggeving ondersteund. Een stimulerende rol is tevens weggelegd voor de ondernemingsraad. De wet op de Ondernemingsraden en de Arbowet bieden daartoe voldoende aanknopingspunten (VROM, 1989: 40; FNV, 1990: 7). Zo is het voor de FNV bijvoorbeeld vanzelfsprekend dat de ondernemingsraad advies zal uitbrengen over het milieuverslag (Stekelenburg, 1989: 81). Echter, enige voorzichtigheid ten aanzien van het inschakelen van werknemersorganisaties op milieugebied is op zijn plaats. De verwachtingen moeten niet te hoog gespannen zijn, onder meer omdat:

- het convenant stroef verloopt (NRC 24/11/ 1989). Bij het concretiseren van de centrale afspraken staken al gauw twistpunten tussen de partijen de kop op (inzake het tempo waarin de maatregelen (moeten) worden uitgevoerd, de wettelijke bescherming van werknemers bij het naar buiten brengen van milieudelicten, en dergelijke);

- het milieubelang kan botsen met het werkgelegenheidsbelang waarvoor de vakbeweging primair staat;

- het milieu dan opgaat in een groter pakket van onderhandelingspunten. Dit brengt het gevaar met zich mee dat het milieubelang, of milieuverslaggeving als onderdeel daarvan, op centraal, bedrijfstak- of ondernemingsniveau wordt afgeruild tegen een ander, of dat het onderhandelingsresultaat een te sterk compromiskarakter draagt;

- de vakbeweging en ondernemingsraden nieuwe deskundigheden zullen moeten aanleren om als gesprekspartners te kunnen optreden;

- CAO-afspraken door de FNV (1990: 8) worden beschouwd als regelingen die vooruitlopen of een aanvulling vormen op een wettelijke regeling. Het streven van de FNV ${ }^{8}$ naar een wettelijk verplicht milieuverslag, met CAO-afspraken als een tussenstap op weg daarnaartoe, staat echter haaks op dat van het georganiseerde bedrijfsleven.

De ontwikkeling van milieuverslaggeving kan ook worden gestimuleerd door als pendant van de PW-prijs op het gebied van de sociale verslaggeving een prijs voor het beste milieuverslag in te stellen. Tevens kan worden gedacht aan 'richtlijnen' van de Raad voor de Jaarverslaggeving, die voor dit doel wordt uitgebreid met één of meer milieu-vertegenwoordigers. Overigens, met betrekking tot jurering en prijstoekenning door het blad PW constateren Dekker \& Van Hoorn 


\section{MAB}

(1989: 137) dat deze een aanvankelijk kwaliteitsverhogende werking hebben moeten bekopen met een duidelijke verstarring in de ontwikkeling van sociale verslaggeving. Het bleek namelijk dat bekroonde verslagen simpelweg werden nageschreven door andere bedrijven. Kennelijk gaat elke vorm van regelgeving gepaard met een zekere mate van verstarring.

Convenanten, CAO's, afspraken met de ondernemingsraad, prijstoekenning en richtlijnen van de Raad voor de jaarverslaggeving zijn alle in potentie geschikte alternatieven voor wetgeving, die vooral van nut kunnen zijn in de komende tijd waarin met milieuverslaggeving moet worden geëxperimenteerd. Het grote voordeel van deze alternatieven, of van combinaties daartussen, is dat ze de betrokken partijen in staat stellen de ontwikkeling van milieuverslaggeving mede te sturen. Dat kan de maatschappelijke acceptatie van het milieuverslag ten goede komen. Daarnaast kunnen ze zicht bieden op knelpunten als de gewenste vorm en inhoud van het milieuverslag, de maatschappelijke behoefte aan milieuverslagen, de (on)mogelijkheden van wetgeving (bijvoorbeeld inzake stoffenregistraties) en de mate van geschiktheid van de werknemersorganisaties als waarnemers van het milieubelang. Of daarmee wetgeving kan worden voorkomen, is goeddeels afhankelijk van de betrokkenen zelf. Tot 1995 (met in 1992 een tussenbalans) hebben zij de tijd gekregen van de met wetgeving dreigende overheid om ervaring op te doen met milieuverslaggeving. Het woord is dus aan het maatschappelijk middenveld dat in feite nog met het experimenteren moet beginnen.

Als dit niet gebeurt of slechts teleurstellende ervaringen oplevert, dan zou wetgeving op termijn wel eens onvermijdelijk kunnen zijn.

\section{Een milieuparagraaf in het bestuurs-, sociale of arboverslag}

Tot slot kan worden gedacht aan het opnemen van een milieuparagraaf in het bestuursverslag of het sociale jaarverslag. Mits het niet reeds is geintegreerd in het sociale verslag, is ook het arboverslag een mogelijk medium. Dit laatste wordt merkwaardigerwijs door niemand voorgesteld, terwijl toch in vrijwel alle publikaties wordt gesignaleerd dat het milieu raakvlakken heeft met de typische arbo-aspecten zoals veiligheid en gezondheid (onder meer VNO/NCW, 1988: 10; VROM, 1989: 14).

Deze vijfde optie wordt gekenmerkt door vrijwilligheid en eenzijdigheid (tenzij er bijvoorbeeld milieubepalingen worden opgenomen in artikel 391 lid 2 BW 2, waarin de inhoudseisen ten aanzien van het bestuursverslag zijn geregeld, of in de Arbowet). In deze kenmerken schuilt haar aantrekkelijkheid voor de werkgevers, die vinden dat BIM's niet gepaard moeten gaan met nieuwe regelgeving (VNO/NCW, 1986: 9).

$\mathrm{Er}$ is veel voor te zeggen het bedrijfsleven experimenteerruimte te gunnen. Experimenten zijn niet alleen nodig om allerlei knelpunten rond milieuverslaggeving op te lossen, maar ook om te onderzoeken op welke wijze milieuzaken kunnen worden geïntegreerd met sociale en arbo-aspecten of met de andere aspecten van de bedrijfsvoering (inkoop, onderzoek \& ontwikkeling, kwaliteitszorg, enzovoort). Integratie van milieuzorg in de totale bedrijfsvoering is namelijk een essentieel element van het BIM (zie noot 1). De overheid geeft daarmee aan dat zij de mate van deze integratie een belangrijke graadmeter vindt voor de mate waarin het bedrijf serieus vorm geeft aan zijn eigen milieu-verantwoordelijkheid. De wijze waarop de integratie heeft plaatsgevonden, zou zijn weerslag kunnen vinden in het sociale, arboof bestuursverslag. Sterker nog, of het milieu daadwerkelijk in het bedrijfsbeleid is geïntegreerd, zou men moeten kunnen aflezen aan de al dan niet samenhangende wijze waarop het in de verslaggeving wordt behandeld.

Tekent zich hier een interessante ontwikkeling af? Een informatieverstrekking waarbij de sociale, arbo-, milieu- en andere bedrijfsvoeringsaspecten in het sociale, arbo- of bestuursverslag worden geïntegreerd, begint verdacht veel te lijken op een maatschappelijk verslag. Het grote voordeel daarvan zou zijn dat het gefragmentariseerde beeld dat van de onderneming ontstaat door de huidige gedifferentieerde wijze van berichtgeving, wordt aangevuld met een geïntegreerd verslag waarin juist verbanden worden gelegd. Een dergelijk verslag zou de 'kroon' op de onderne- 


\section{MAB}

mingsberichtgeving kunnen worden. Komt de maatschappelijke berichtgevingstheorie via deze omweg, maar nu zonder direct te refereren aan de informatiegebruikers, dan toch terug?

De vrijwilligheid en eenzijdigheid van deze optie kunnen echter niet uitsluitend als positief worden beschouwd. Het ontbreken van sanctiemiddelen op een te trage ontwikkeling van milieuverslaggeving en het goeddeels uitsluiten van de milieu- en werknemersorganisaties bij deze ontwikkeling maken deze optie te vrijblijvend en te afhankelijk van de goede wil van één partij. Gevreesd moet dan worden dat milieuverslaggeving niet goed op gang komt.

\section{Afsluitende opmerkingen}

Het milieuverslag lijkt er aan te komen, al liggen de meningen over dit nieuwe periodieke ondernemingsbericht verdeeld. De pleidooien voor milieuverslaggeving variëren van vrijwillige experimenten (werkgevers) tot en met verankering in wetgeving met verplichte controle door externe deskundigen (milieu- en werknemersorganisaties). De overheid heeft voorlopig afgezien van wetgeving, maar houdt deze mogelijkheid nadrukkelijk open. Onder de bredere discussie rond BIM wordt derhalve een fel debat over milieuverslaggeving gevoerd.

Wanneer aan wetgeving wordt gedacht, kunnen Titel 9 BW 2 en de Arbowet model staan. Nog bestaande onduidelijkheden over onder meer de vorm, inhoud (stoffenregistraties?) en externe controle (milieu-accountant?) van het milieuverslag maken het echter te vroeg om reeds nu een Wet op het Milieuverslag van Ondernemingen als pendant van Titel 9 BW 2 of een raamwet als pendant van de Arbowet voor te bereiden. Een geleidelijke ontwikkeling waarbij eerst met milieuverslaggeving wordt geëxperimenteerd, waarop ook de overheid doelt, is meer op haar plaats. Daarmee vallen twee van de vijf in dit artikel behandelde opties voor milieuverslaggeving vooralsnog af. In de verdere toekomst zouden ze echter aan belang kunnen winnen.

Oplossingen voor milieuproblemen, en dus ook voor milieuverslaggeving, verlangen een breed maatschappelijk draagvlak. Het is van groot belang dat oplossingen door alle betrokkenen in belangrijke mate worden geaccepteerd. Mede hierom wordt het opnemen van een milieuparagraaf in het bestuurs- of sociale verslag, dat door de werkgevers wordt voorgesteld, of in het arboverslag, als te vrijblijvend en te eenzijdig afgewezen. De keerzijde daarvan is wellicht dat een spontane ontwikkeling naar een geïntegreerd maatschappelijk verslag wordt afgesneden.

Een terugkeer van de 'traditionele' maatschappelijke berichtgevingstheorie wordt tevens afgewezen als optie, onder meer doordat onduidelijk is wie als informatiegebruikers moeten worden bestempeld en wat hun informatiebehoeften dan wel zouden zijn.

Er rest dan nog één optie. Het milieuverslag zou zich kunnen ontwikkelen zoals destijds het sociale verslag. Door privaatrechtelijke vormen van regelgeving toe te passen lijkt een succesvolle en geleidelijke ontwikkeling van milieuverslaggeving beter te kunnen worden gegarandeerd. Mogelijke vormen als convenanten, CAO's, afspraken met de ondernemingsraad, prijstoekenning en richtlijnen van de Raad voor de Jaarverslaggeving verhogen de druk op de werkgevers om milieuverslaggeving serieus te nemen, en bevorderen de participatie van en overleg met de overige betrokkenen. Ze vereisen wel bereidwilligheid en creativiteit bij alle betrokken partijen. Deze partijen zullen zich dat realiseren, want naarmate zij er minder in slagen om in onderling overleg tot overeenstemming te komen over knelpunten als de vorm, inhoud en controle van milieuverslaggeving, komt een ingreep van de wetgever naderbij.

Mocht het zover komen, bijvoorbeeld als de wetgever op een zeker moment vindt dat te weinig bedrijven zijn overgegaan tot milieuverslaggeving, dan zou ik willen pleiten voor de totstandkoming van een raamwet. Daarmee blijven behoorlijke vrijheden ten aanzien van het aanpassen van de regelgeving aan branche-specifieke situaties behouden. Een wet a la de Arbowet derhalve met die uitzondering dat mijns inziens, indien controle-technisch mogelijk, een geprivatiseerde vorm van externe controle de voorkeur verdient. Uit het principe 'de vervuiler betaalt' volgt namelijk dat de controlekosten ten laste dienen te komen van het bedrijfsleven. 


\section{Noten}

1 Een BIM wordt gedefinieerd als de systematische toepassing door het bedrijf van het geheel van voorzieningen, gericht op het inzicht krijgen in, het beheersen van en het waar mogelijk beperken van de beinvloeding van het milieu door de bedrijfsactiviteiten (NROM. 1989: 21). Het bevat de volgende elementen (VROM, 1989: 1)

- milieubeleidsverklaring:

- milieuprogramma;

- integratie van milieuzorg in de bedrijfsvoering;

- metingen en registraties;

- interne controles;

- interne voorlichting en opleiding;

- in- en externe rapportage;

- verificatie van het milieuzorgsysteem (bijvoorbeeld door audits).

2 Dit betreft met name de voedings-, metaal-,

kunststofverwerkings- en chemische industrie. De grotere bedrijven worden van de kleinere onderscheiden op grond van de vergunningsvoorschriften. Zo dienen bijvoorbeeld alle bedrijven die een vergunning behoeven op rijks- of provinciaal niveau een integraal BIM te implementeren (zie verder VROM. 1989: 23).

3 De term milieurapportage wordt gereserveerd voor de informatieverstrekking aan de overheid, terwijl de term milieuverslag zowel de informatieverstrekking aan de overheid als aan derden betreft (VROM, 1989: 26).

4 Het bevoegd gezag is het college van Burgemeester en Wethouders, Gedeputeerde Staten of de Kroon, hetgeen onder meer afhankelijk is van de vestigingsplaats(en) van de inrichting (zie verder Kivits, e.a., 1989: 17).

5 In bedrijven of instellingen behorende tot een bij AMvB aangewezen categorie moet het beleid gericht op veiligheid, gezondheid en welzijn door de werkgever jaarlijks in de vorm van een schrittelijk plan voor een periode van ten minste één jaar worden vastgelegd (artikel 4 , lid 3 van de Arbowet). Deze bepaling is per 1 oktober 1990 van kracht geworden.

6 Onder een code verstaat Van Hoorn (1981: 113) een door een aantal ondernemers gezamenlijk gemaakte afspraak om zich met betrekking tot sociale berichtgeving aan een aantal overeengekomen regels te houden. Eventuele 'richtlijnen' van (een pendant van) de Raad voor de Jaarverslaggeving kunnen worden opgevat als een tweede type code. Het sociaal statuut (:117) is een vorm van overeenkomst tussen de onderneming en de representatieve vakorganisaties omtrent doelstellingen van, visie op en inhoud van het sociale beleid en geplande ontwikkelingen daarvan. De opdracht tot regelgeving $(: 111)$ betreft een opdracht van de overheid aan werkgevers, vakorganisaties en/of ondernemingsraad de aangegeven materie te regelen. Tot slot, afspraken tussen de sociale partners kunnen ook tot stand komen in de Stichting van de Arbeid en de Sociaal-Economische Raad (:112).

7 De overige werkgeversorganisaties NCW, KNOV en NCOV en de vakcentrales CNV en MHP sloten zich later aan bij dit overleg. 8 Van de vakcentrales CNV en MHP zijn geen relevante publikaties over BIM's bekend.

\section{Literatuur}

Bindenga, A. J., De bedriffeconomische basis van de accountancy, Samsom. Alphen aan den Rijn, 1981.

Bindenga, A. J., Interview met de Volkskrant d.d. 10 juli 1989.

Blokdijk. J. H., Milieu en accountant, Maandblad voor Accountancy en Bedriffseconomie, maart 1989: pp. 85-88.

Brink, H. L., 's Lands wijs, 's lands eer, Wolters-Noordhoff, Groningen, 1989.

Dekker, H. C., Enige ontwikkelingen betreffende maatschappelijke berichtgeving, in: Dorsman, A. B. \& Huizing, A., Organisaties in het web van hun omgeving, Vermande, Lelystad, 1989: pp. 140-150.

Dekker, H. C. \& Van Hoorn, Th. P., Sociale verslaggeving: hefboom tot vermaatschappelijking?, in: Dorsman, A. B. \& Huizing, A., Organisaties in het web van hun omgeving. Vermande, Lelystad, 1989: pp. 126-139.

Derwent, R.. A mandate for green reporting, Accountancy, October 1989: pp. 92-94.

ᄃNV, Reactie op de notitie Bedrijfsinterne milieuzorg, Amsterdam, 1990.

Hoorn, Th. P. van, Regelgeving voor sociale berichtgeving: criteria en alternatieven, in: Dekker, H. C. e.a., Sociale rekenschap, SMO, boek 19, 1981: pp. 93-130.

Huizing, A., De gebruikersbenadering: gewenste feiten? Maandblad voor Accountancy en Bedrifshuishoudkunde, januari 1987: pp. 13-24.

Kivits, H. G. e.a., Info milieuzorg, VUGA Uitgeverij B.V., 1989.

Limperg Instituut, Periodieke berichtgeving door ondernemingen, Limperg Instituut, Amsterdam, 1984.

LMO, Ideeën voor milieuzorg, Landelijk Milieu Overleg, Utrecht, 1989.

Nationaal Milieubeleidsplan, SDU uitgeverij, 's-Gravenhage, 1989.

NRC-Handelsblad, 24 november 1989.

Piet, J. L. P., Administratieve organisatie van afvalstoffen in produktiebedrijven, Maandblad voor Accountancy en Bedrijfseconomie, juni 1990: pp. 248-253.

Poel, J. H. R. van de, Als de tekenen bedriegen ..., WoltersNoordhof, Groningen, 1988.

Schreuder, H., Maatschappelijke verantwoordelijkheid en maatschappelijke berichtgeving van ondernemingen, Stenfert Kroese, Leiden/Antwerpen, 1981.

Stekelenburg, J., Accountant en milieu, in: J. R. van Helvoort e.a. (red.). Entering the nineties, verkenningen naar morgen, Den Haag, 1989: pp. 78-83.

VNO/FNV, Gemeenschappelijke verklaring over het milieubeleid, 's-Gravenhage, 1989.

VNO/NCW, Milieu-accountancy in ondernemingen, Verbond van Nederlandse Ondernemingen en Nederlands Christelijk Werkgeversverbond, 's-Gravenhage, 1985.

VNO/NCW, Milieuzorg in bedrijven, 's-Gravenhage, 1986.

VNO/NCW, Onderneming en milieu, 's-Gravenhage, 1988.

VNO/NCW, Milieuzorg in bedrijven, 's-Gravenhage, 1990.

VROM, Bedriffsinterne Milieuzorg, Ministerie van Volksgezondheid, Ruimtelijke Ordening en Milieu, 1989.

Wilschut, K. P. G., Twintig stellingen rondom de bemoeienis van accountants met de milieuproblematiek, De Accountant, september 1990: pp. 15-17. 